Int. J. Dev. Biol. 62: 847-856 (2018)

https://doi.org/10.1387/ijdb.180206at

\title{
HOX genes in normal, engineered and malignant hematopoiesis
}

\author{
EMMA M. COLLINS and ALEXANDER THOMPSON* \\ University of Nottingham, Division of Cancer and Stem cells, Centre for Biomolecular Sciences University Park, \\ Nottingham, UK
}

\begin{abstract}
Advanced technologies and models systems are improving our understanding of developmental processes. A primary example, hematopoiesis, classically represented by a hierarchical tree with a stem cell at the apex and more lineage restricted cells following each bifurcation has recently been shown to be capable of more adaptable fate decisions. Future research will identify key molecules underpinning this more adaptable or continuous model of hematopoiesis potentially leading to improved engineering of blood cells and therapies for malignant disease. The spatio-temporal, cell specific and exquisite reliance on gene dosage attributed to the HOX family promoted them as candidate master regulators of hierarchical hematopoiesis. Recent discoveries in the need to stimulate or retain HOX expression during engineered human hematopoiesis, supported by similar studies in mice and other developmental models, reinforces their importance at the single cell level. Likewise, dysregulation of $H O X$ in single cells can result in blood cancers such as leukemia. It will be of interest to see what additional roles HOX family members and their regulators including morphogens, epigenetic modifiers and noncoding RNAs play in this evolving field and if these master regulators can be further harnessed for clinical benefit.
\end{abstract}

KEY WORDS: HOX, hematopoiesis, stem cell, acute myeloid leukemia

\section{Hematopoietic HOX genes}

Mammalian Hox genes are a family of 39 homeodomain-containing transcription factors, organised into four distinct clusters: Hoxa, Hoxb, Hoxc and Hoxd. With the exception of the Hoxd cluster, Hox genes have key roles in hematopoiesis, particularly in regulating primitive hematopoietic cells (Thorsteinsdottir et al., 1997; Argiropoulos and Humphries, 2007). During hematopoeisis, Hox genes are mostly expressed in CD34+, hematopoietic stem cell (HSC)-enriched, populations and downregulated upon differentiation or lineage commitment (Sauvageau et al., 1994; Pineault et al., 2002).

\section{Gain-of-function}

Due to their high homology, overexpression studies in mouse have been useful in further elucidating the role of individual Hox genes in hematopoiesis. Overexpression of HOXB3 in mouse bone marrow cells resulted in impairment of $T$ and $B$ lymphocyte development and excessive myeloid proliferation in transplanted mice (Sauvageau et al., 1997). HOXB4 overexpression in murine bone marrow cells had a profound effect on HSC proliferation, enhancing HSC repopulating ability both in vitro and in vivo (Sauvageau et al., 1995). A similar positive regulation of hematopoietic cell growth was also seen in human cord blood stem cells, where constitutive expression of $\mathrm{HOXB} 4$ led to increases in $\mathrm{CD} 34^{+}$stem cell number (Buske et al., 2002). Similar to the studies of HOXB

Abbreviations used in this paper: AGM, aorta-gonad-mesonephros; AML, acute myeloid leukemia; BMI-1, B cell-specific Moloney murine leukemia virus integration site 1; BMP, bone morphogenetic protein; CDX, caudal type homeobox; EHT, endothelial-to-hematopoietic transition; ERG, ETS-related gene; ESC, embryonic stem cell; FGF, fibroblast growth factor; FLT3, FMS-like tyrosine kinase 3; HEP, hemogenic endothelium progenitor; HOX, class I homeobox; hPSC, human pluripotent stem cell; HSC, hematopoietic stem cell; HSPC, hematopoietic stem and progenitor cell; KDR, vascular endothelial growth factor receptor 2; LCOR, ligand dependent nuclear receptor corepressor; Meis1, myeloid ecotropic viral integration site 1; MLL/KDM5a, mixed-lineage leukaemia; MYB, myeloblastosis oncogene; NPM1, nucleophosmin-1; PBX, pre-B-cell leukemia homeobox; PRC, polycomb gene ( $\mathrm{PcG}$ ) repressor complex; PSC, pluripotent stem cell; RA, retinoic acid; RORA, retinoic acid receptor related orphan receptor A; RUNX, runt-related transcription factor; SOX, SRY-related HMG-box; SPI1, spleen focus forming virus (SFFV) proviral integration oncogene-1; TALE, three-amino-acid-loopedextension; Wnt, wingless and INT-1.

\footnotetext{
*Address correspondence to: AlexanderThompson. University of Nottingham, Division of Cancer and Stem cells, Centre for Biomolecular Sciences University Park, Nottingham NG7 2RD, UK. E: Alex.Thompson@ nottingham.ac.uk -T: +44 (0) 1158231234

W: https://www.nottingham.ac.uk/medicine/about/cancerandstemcells/people/alex.thompson - (iD) https://orcid.org/0000-0002-9315-5321
}

Submitted: 3 July, 2018; Accepted: 13 September, 2018.

ISSN: Online 1696-3547, Print 0214-6282 
cluster, transplantation of hoxa9-overexpressing mouse HSCs resulted in enhanced HSC self-renewal capacity and myelopoiesis (Thorsteinsdottir et al., 2002). Overexpression of HOXA9 in human embryonic stem cells (ESCs) had a positive outcome, enhancing the generation of hemogenic endothelium progenitors and subsequently primitive and total blood cells (Ramos-Mejía et al., 2014). Whereas, ectopic expression of HOXA5 and overexpression of HOXA10 in human $\mathrm{CD} 34^{+}$cord blood cells blocked erythroid differentiation and increased myelopoiesis (Crooks et al., 1999; Buske et al., 2001).

\section{Loss-of-function}

While these overexpression studies indicate a key role for HOXA and HOXB cluster genes in regulating the activity of primitive hematopoietic cells, knockdown studies, for the most part, do not support such a role. Despite its striking effect on HSC self-renewal in overexpression experiments, knockdown of hoxb4 had no apparent effect on normal HSC activity. Moreover, knockdown of the majority of the hoxb cluster, from hoxb1-b9, did not affect the repopulating activity of fetal liver cells or result in any hematopoietic defective phenotype, implying the Hoxb cluster is nonessential for early hematopoietic cell function (Bijl et al., 2006).

Functional redundancy within the Hoxnetwork may hamper such knockout studies and explain the lack of abnormal phenotypes. However, while knockdown of most HOX genes have little effect on hematopoiesis, Hoxa9knockdown produces the most profound effect, with disturbances in differentiation and HSC self-renewal (Alharbi et al., 2013). Hoxa9 knockout mice have depleted myeloid, erythroid and B cell progenitors in the bone marrow and a $30-40 \%$ reduction in leukocytes (Lawrence et al., 1997). HSCs obtained from hoxa9-/ mice have diminished repopulation ability in contrast to hoxa 10/- HSCs where repopulating activity was unaffected. (Lawrence et al., 2014). Additionally, the repopulating ability of HSCs derived from either hoxa9 or compound hoxa9/hoxb3/ hoxb4 null mice were similarly reduced (Magnusson et al., 2007).

Interestingly, deletion of the whole Hoxa cluster in mice reduced hematopoietic stem and progenitor cell (HSPC) proliferation in vitro and engraftment potential in vivo, however, HSPC activity could be partially restored to wild-type levels through overexpression of hoxa9 (Lebert-Ghali et al., 2016). These studies clearly demonstrate a role for Hoxa9 in regulating HSC function and in vivo engraftment.

\section{Embryonic hematopoietic development}

The in vitro differentiation of mouse embryonic stem cells (ESCs) to cells of the hematopoietic lineage has been found to largely parallel hematopoiesis in the developing mouse embryo (Keller, 1995). As such, recapitulation of this natural pathway using pluripotent stem cell (PSC) cultures is regarded as the best method to generate bona fide HSCs (Yoder, 2014). Hematopoiesis takes place in three distinct waves in the mouse embryo.

\section{Primitive hematopoiesis}

In the first wave, BMP4, FGF2, Wnt and Nodal signalling are crucial in patterning of the primitive streak and formation of early mesoderm. Migrating mesoderm from the early primitive streak, marked by co-expression of kinase inert domain-containing factor (KDR) and Brachyury, forms the yolk sac followed by blood islands and endothelium (Ferkowicz and Yoder, 2005; Ackermann et al., 2015). The yolk sac generates the first hematopoietic cells, primitive erythroid progenitors. These progenitors subsequently give rise to primitive erythroblasts, macrophages and megakaryocytes but do not generate HSCs or lymphoid cells. As such, the first wave is also described as 'primitive hematopoiesis' (Yoder, 2014). Hoxa9 and hoxc9 were identified as being highly expressed in the visceral yolk sac (E7.5) and subsequently dispersed within the yolk sac and embryo (E8.5) associated with insulin induction and primitive erythroblast formation (Mcgrath and Palis, 1997).

\section{Transient definitive hematopoiesis}

The second wave (E8.25-E10.5) is marked by the appearance of erythromyeloid progenitors from the hemogenic endothelium in the blood island capillaries of the yolk sac. Erythromyeloid progenitors initially develop as clusters of cells in the blood islands, which then detach and enter blood circulation (Yoder, 2014). Cells of the hemogenic endothelium are capable of generating $B$ and $T$ lymphoid progenitors (Böiers et al., 2013). Since erythromyeloid cells have multi-lineage differentiation potential, the second wave is considered 'transient definitive hematopoiesis', distinguished by specific globin expression in their progeny (McGrath and Palis, 2005). However, these transient cells lack self-renewal capacity and lymphoid potential (Kyba and Daley, 2003; Mikkola, 2006).

\section{Definitive hematopoiesis}

The third wave is considered 'definitive hematopoiesis' as it gives rise to definitive HSCs, capable of long-term repopulation and generating all hematopoietic cell types. HSCs arise from a subset of specialised hemogenic endothelial cells in the dorsal aorta of the aorta-gonad-mesonephros (AGM) through an endothelial-tohematopoietic transition (EHT) (Ackermann et al., 2015). In the process of EHT, the hemogenic endothelium loses its endothelial potential and undergoes a commitment to the hematopoietic lineage (Swiers et al., 2013). Following specification from the hemogenic endothelium, HSCs migrate out of the dorsal aorta and eventually colonise the bone marrow. Hox co-factor Meis1 and mixed-lineage leukaemia (MII, also known as KMT2A), a histone methyltransferase that regulates $\mathrm{HOX}$ genes expression through methylation of histone 3 lysine 4 residues on HOX promoters, are both expressed in the AGM and are essential for definitive hematopoiesis (Ernst et al., 2004; Azcoitia et al., 2005).

\section{Hematopoietic differentiation of pluripotent stem cells}

Most in vitro hematopoietic differentiation protocols are based on mimicking the distinct signalling cascades which occur during hematopoiesis in vivo. BMP4, FGF2 and Wnt are known to be crucial factors in the generation of early hematopoietic progenitors during embryonic development and are also essential in initiating in vitro differentiation to hematopoietic lineage (Chadwick et al., 2003; Wang and Nakayama, 2009). As definitive hematopoietic cells arise from the hemogenic endothelium, the hemogenic endothelium has also been used as a source of definitive hematopoietic cells. Choi et al., (2012) identified hemogenic endothelium progenitors (HEPs) capable of forming definitive hematopoietic cells could be characterised by expression of VE-cadherin and lack of CD73, CD43 and CD235a. RUNX1 isoform c (RUNX1c) was similarly identified as necessary in specification of human pluripotent stem cell (hPSC)-derived HEPs. Deletion of $R U N X 1 c$ did not impact the generation of HEPs from hPSCs but greatly impaired the generation 
of CD45+ blood cells from HEPS (Navarro-Montero et al., 2017). This is in accordance with embryonic development where Runx1 marks HSC emergence (North et al., 2002).

\section{PSC-derived hematopoietic differentiation}

While, these initial PSC-derived differentiation systems showed success in generating definitive hematopoietic cells, they are still incapable of generating multi-lineage cells with long-term engraftment potential, which are core features of bona fide HSCs. Contrary to embryonic development where primitive and definitive hematopoiesis occur in three distinct waves, in PSC-derived differentiation systems these phases occur simultaneously (Ackermann et al., 2015). As both primitive and definitive systems result in the generation of $\mathrm{CD} 34^{\text {th }}$ hematopoietic cells, differentiated cells cannot be distinguished based solely on CD34 positivity. However, the two programs can be distinguished based on functional end-point analyses, such as T lymphocyte formation ability, and based on responses during the differentiation process. Activin/Nodal signalling stimulates primitive hematopoiesis, therefore inhibitors of this pathway are used to initiate definitive hematopoiesis (Kennedy et al., 2012). CD235a is a marker of primitive hematopoiesis that appears to provide a means of identifying and thus discriminating

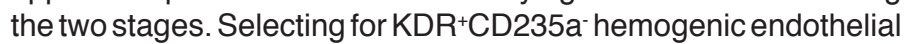
precursors along with Wnt signalling activation led to generation of $\mathrm{CD}_{4} 5^{+}$hematopoietic cells capable of producing primitive $\mathrm{T}$ lymphocytes and erythroid and myeloid cells in colony-forming unit (CFU) assays (Sturgeon et al., 2014).

\section{BMP/Wnt-Cdx-Hox axis}

Generation of long-term repopulating HSCs remains a major challenge for hPSC-based hematopoietic differentiation systems. Hoxgenes are key regulators of embryonic hematopoiesis and are implicated in $\mathrm{HSC}$ self-renewal. As such, induction of Hoxsignalling in differentiating cultures may activate key pathways responsible for development of HSCs. The caudal-type homeobox $(\mathrm{Cdx})$ gene family, consisting of $C d x 1-4$, are upstream regulators of $H O X$ which regulate hematopoiesis in zebrafish, mice and humans (Rawat et al., 2012). Deletion of $C d x 2$ in mouse ESCs compromised the formation of embryonic hematopoietic progenitors and resulted in aberrant expression of posterior or 5' Hoxa genes. Hox gene expression levels were restored by ectopic expression of $\mathrm{Cdx} 4$, demonstrating Hox expression is initiated and closely regulated by $C d x$ genes (Wang et al., 2008). Moreover, in a follow up to Sturgeon's study, upregulation of $C D X 1, C D X 2$ and $C D X 4$ was observed exclusively in Wnt-dependent $\mathrm{KDR}^{+} \mathrm{CD} 235 \mathrm{a}$ - definitive hematopoietic mesoderm populations. Temporal analysis revealed increased $C D X 4$ expression coincided with addition of Wnt agonist CHIR99021 to the cultures. Overexpression of $C D X 4$ in differentiating cultures yielded the same CD $34^{+} \mathrm{CD} 43^{-} \mathrm{CD} 73{ }^{-} \mathrm{CD} 184^{-}$hemogenic endothelium population as Wnt activation, suggesting Wntmediates definitive hematopoietic specification through activation of CDX4 (Creamer et al., 2017). This approach may have recapitulated a conserved BMP/Wnt-Cdx-Hox axis first identified in parallel studies performed in zebrafish embryos and murine ESCs (reviewed by Lengerke and Daley, 2012).

\section{Acquisition of a HOXA signature}

Recently, $\mathrm{Ng}$ et al., (2016) reported that acquisition of a HOXA signature during lineage specification of hPSCs may underlie the potential of subsequent hematopoietic stem and progenitor cells (HSPCs) to engraft and repopulate recipients long-term. The transcriptional profiles of hESC-derived $\mathrm{CD} 34^{+}$cells incapable of long-term engraftment were compared with long-term repopulating cord blood-derived CD $34^{+}$cells. HOXA cluster genes were identified among the genes significantly downregulated in hESC-derived CD34+ cells. In order to induce HOXA expression, hESC-derived CD34 ${ }^{+}$cells were treated with Activin inhibitor SB431542 and Wnt agonist CHIR99021, resulting in upregulation of HOXA5, HOXA9 and HOXA10 expression. Aorta-like SOX $17^{+}$cells resembling definitive hematopoietic cells of the AGM with myeloid and erythroid differentiation potential were also generated by the SB431542/ CHIR99021 treated cultures. While these SOX $17^{+}$cells did not show repopulating activity, this study demonstrated that HOXA genes not only play a role in regulating definitive hematopoiesis but that acquisition of a HOXA signature signifies specification of the AGM.

Stimulating HOXA gene expression during AGM development may therefore provide a means of generating self-renewing HSCs from PSCs. HOXA genes, in particular HOXA5 and HOXA7, were found to be highly expressed in fetal liver-derived HSPCs while suppressed in hESC-derived HSPCs which lacked repopulation activity. Overexpression of HOXA5 and HOXA7 in hESC-derived CD34+ cells did not enhance HSPC expansion in vitro, however, activation of retinoic acid (RA) signalling during EHT generated HSPCs with enhanced proliferation and also induced expression of HOXA genes. Thus, acquisition of a HOXA signature is developmental stage specific, depends on the presence of HOXA regulatory factors and acts in parallel with other pathways (Dou et al., 2016).

\section{Wnt and RA signalling}

RAhas previously been demonstrated to promote HSC development and is essential for development of hemogenic endothelium in mouse embryos (Goldie et al., 2008). In AGM-derived hemogenic endothelium cultures activation of RA signalling promoted HSC development through downregulation of the $\mathrm{Wnt} / \beta$-catenin pathway (Chanda et al., 2013). However, $\mathrm{Ng}$ et al., (2016) and Sturgeon et al., (2014) both utilised Wnt signalling activation to govern specification of the hemogenic endothelium in PSC-based studies. Thus the requirement for Wnt signalling is evidently stage-dependent.

\section{Transcription factors}

In an alternative transcription factor-driven approach to hematopoietic differentiation, Doulatov et al., (2013) demonstrated transfection of hPSC-derived CD $34^{+} \mathrm{CD} 45^{+}$hematopoietic progenitors with five transcription factors (HOXA9, ERG, RORA, SOX4 and MYB) produced hematopoietic cells capable of short-term myeloid and erythroid engraftment in vivo. Following on from this study, Sugimura et al., (2017) achieved long-term myeloid, $B$ and T cell engraftment of HSPCs generated from hemogenic endothelium transfected with seven transcription factors (ERG, HOXA5, HOXA9, HOXA10, LCOR, RUNX1 and SPI1). Both of these papers demonstrate the importance of HOXA genes, in particular that of HOXA9, in generating HSPCs with long-term multi-lineage repopulating abilities. Furthermore, HOXA9 occupies the promoters of ERG, MYB, SOX4 and SPI1 (Huang et al., 2012), suggesting it is a crucial factor in obtaining repopulating activity.

As models have become more defined our understanding of the molecular basis for HSPC production has improved (Fig. 1.) Although further follow-up analyses are required, recent approaches 
by the Daley (Sugimura et al., 2017) and Elefanty (Ng et al., 2016) laboratories along with studies on $\mathrm{Cdx}$-Hox expression (Rawat et al., 2012) provide strong support that acquirement of a HOXA signature is a key process in definitive hematopoiesis. Interestingly, acquisition and retention of a HOXA signature also appears to be key in malignant hematopoiesis.

\section{HOX genes in acute myeloid leukemia}

HOX genes are frequently dysregulated in leukemias. In acute myeloid leukemia (AML), HOX genes have been shown to induce or promote AML by forming oncogenic fusion proteins or collaborating with other AML-inducing mutations (Alharbi et al., 2013). Upregulation of HOX genes and their co-factors, such as MEIS1, is associated with an unfavourable outcome in AML (Andreeff et al., 2008). In particular, expression of HOXA9 was found to be the main determinant of poor prognosis in a cohort of AML patients (Golub et al., 1999). HOXA9 is overexpressed by $2-8$ fold in approximately $50 \%$ of all AML cases (Li et al., 2013; Collins et al., 2014). As HOXA9 has many downstream targets, which also confer poor prognosis in AML, it is unclear how central a role HOXA9 plays in the outcome of the disease phenotype (Collins and Hess, 2016). In terms of a direct role of HOXA9 in leukemogenesis, HOXA9 expression alone does not appear to be sufficient. Hoxa9 overexpression failed to transform mouse bone marrow cells, however, co-overexpression with three-amino-acid-looped-extension (TALE) co-factor genes MEIS1 or $P B X 3$ produced rapid leukemic transformation ( $\mathrm{Li}$ et al., 2016). In fact, HOXA9 and MEIS1 are frequently co-expressed in myeloid leukemias (Lawrence et al., 1999). Therefore, it appears Hoxa9 does not solely induce leukemogenesis but requires other collaborating factors, such as Meis 1 or fusion to nucleoporin 98 (NUP98).

\section{NUP98-fusion proteins}

HOX fusions with NUP98 were first reported to be involved in leukemia with the identification of NUP98-HOXA9 fusion gene in AML patients. Subsequently, 28 other distinct fusion partner genes were identified in patients with leukemia, including six from the HOX family, demonstrating a direct link between HOX genes and leukemia (Gough et al., 2011). The most commonly occurring NUP98 fusion, NUP98-HOXA9, was shown to be directly involved in the pathogenesis of leukemia, producing a myeloid-proliferative disease, which progressed into AML in mice transplanted with NUP98-HOXA9-transduced bone marrow cells (Kroon, 2001). 5 HOX genes, including HOXA11, HOXA13, HOXC13 and HOXD13, have all been identified as fusion partners with NUP98 (Gough et al., 2011), suggesting the ability of NUP98-HOX fusions to form leukemia is restricted to posterior HOX genes. Using novel NUP98-

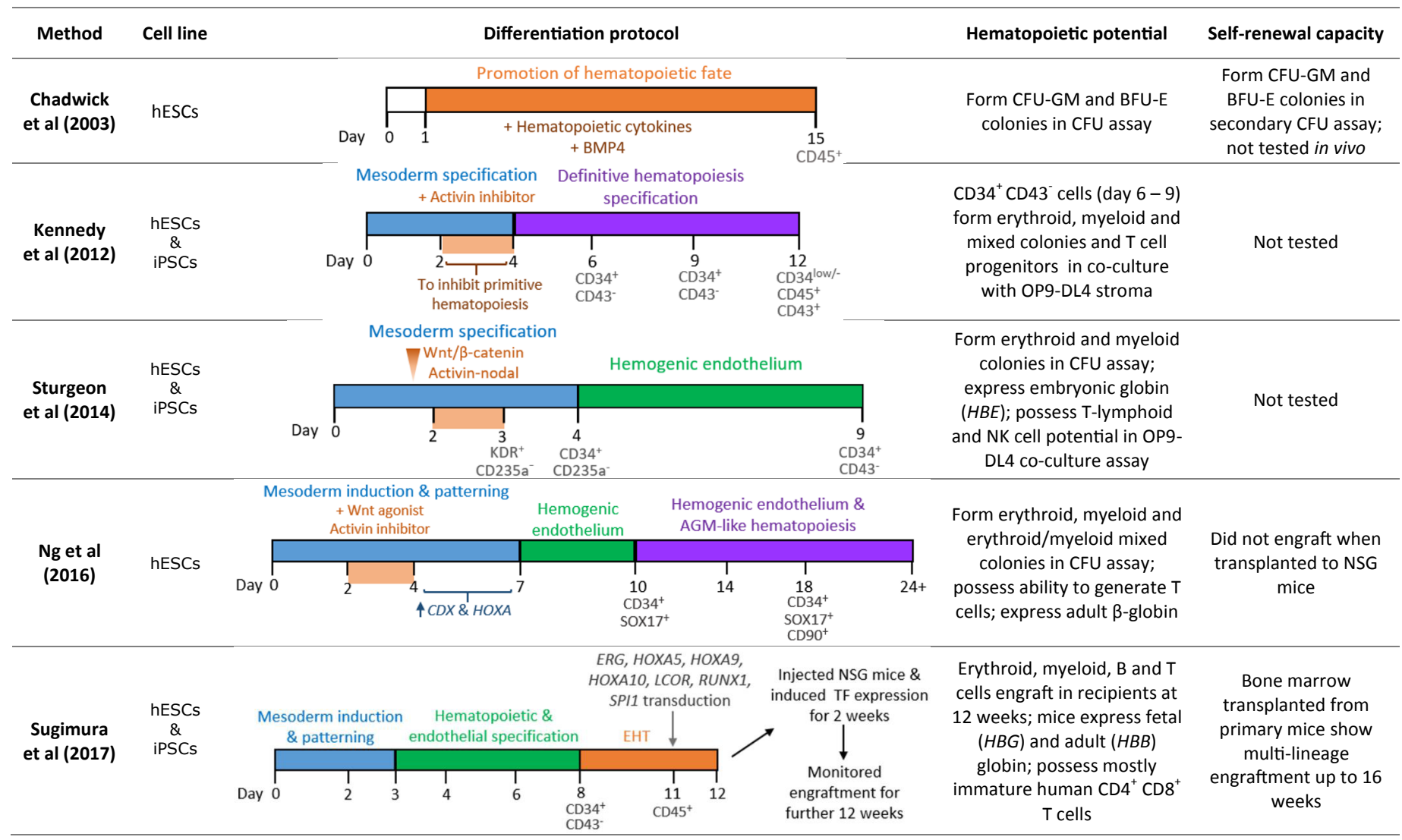

Fig. 1. Methods of pluripotent stem cell differentiation to hematopoietic stem and progenitor cells (HSPCs). Summary of key differentiation methods from the literature are outlined, with illustrations focusing on the most important features of each differentiation method. The hematopoietic potential and self-renewal capacity of the resulting HSPCs from each method is also highlighted. Abbreviations: CFU, colony-forming unit; EB, embryoid body; EHT, endothelial-to-hematopoietic transition; hESC, human embryonic stem cell; HSPC, hematopoietic stem and progenitor cell; iPSC, induced pluripotent stem cell; NSG, NOD/LtSz-scidIL2Rynull; PSC, pluripotent stem cell. 
HOX fusions not detected in humans, leukemia was induced in murine transplant models with HOXA10 and HOXB3 as fusion partners, but not HOXB4 (Pineault et al., 2004). Interestingly, coexpression of the Hox co-factor Meis 1 with all NUP98-HOX fusions tested accelerated the development of AML. This indicates all $\mathrm{HOX}$ genes, not just 5' HOX genes, possess an intrinsic ability to become leukemogenic (Kroon, 2001; Pineault et al., 2004).

\section{MLL-fusion proteins}

MLL rearrangements are found in over $70 \%$ of infant leukemias and approximately $10 \%$ of adult and therapy-related AMLs. They are formed by gross chromosomal translocations at the 11q23 locus, producing fusion genes which comprise of the $\mathrm{N}$-terminus of MLL fused to the C-terminal of its fusion partner gene (Krivtsov and Armstrong, 2007). MLL has over 88 different fusion partners, however, over $80 \%$ of $M L L$ fusion genes result from translocation with AF4, AF9, ENL, AF10, ELLor AF6(Meyer etal., 2017). A partial tandem duplication (PTD) in the N-terminus of MLL can also take place, occurring in approximately $12 \%$ of AML cases (Basecke et al., 2006; Meyer et al., 2017). Aberrant HOX gene expression is implicated in all MLL-rearranged myeloid and lymphoblastic leukemias (Armstrong et al., 2002). In particular, upregulation of HOXA9and MEIS1 solely in MLL-rearranged subtype of leukemias suggests they are directly involved in MLL-induced leukemogenesis (Yeoh et al., 2002).

As MLL regulates $\mathrm{HOX}$ genes expression, dysregulated $\mathrm{HOX}$ expression in response to MLL fusion genes is expected. Interestingly, the SET domain responsible for MLL methylation activity is lost during translocation. However, fusion partners AF4, AF9, AF10 and ENL all coordinate with histone methyltransferase DOT1L, an activity which is maintained following translocation. Therefore, as some MLL fusion proteins are chromatin modifiers themselves, it is proposed that MLL fusion proteins mediate their effects on $\mathrm{HOX}$ expression via DOT1L(Krivtsov and Armstrong, 2007; Slany, 2009).

Several studies in mice and immortalised leukemic cell lines have indicated the acquisition and retention of a 5' Hoxa signature may be a requirement in MLL-mediated leukemogenesis (Horton et al., 2005). Mouse primary myeloid progenitor lines immortalized with MLL oncogenes (MLL-ENL, MLL-AF6, MLL-CBP, MLL-ELL and $M L L-A F 10$ ) displayed a 5' Hoxa profile, whereby 5' Hoxa genes, including Hoxa7 and Hoxa9, were expressed in all lines while 3' Hoxa genes were expressed less regularly. Moreover, in contrast to wild-type cells, Hoxa9-/-bone marrow cells transduced with $M L L-E N L$ displayed severely impaired replating ability and failed to generate leukemia following transplantation into mice. This indicates a crucial role for Hoxa9 both in maintenance and initiation of MLL-ENL-mediated leukemogenesis (Ayton and Cleary, 2003). Contrary to this finding, Kumar et al., (2004) observed no deficiency in leukemia initiation or latency in Hoxa9-/ mice following knock-in of oncogene MLL-AF9. The leukemogenic potential of Hoxa9-- mice was equivalent to wild-type, although mice deficient in Hoxa9 showed a more immature myeloid phenotype. However, elevated 5' Hoxa levels was observed in all mice, consistent with a role of Hox genes in MLL-mediated leukemia. Mice transplanted with HOXA9-deficient human MLL-rearranged SEMK2 cells also exhibit reduced leukemia burden, implicating HOXA9 in leukemia survival in vivo (Faber et al., 2009). The differences in outcomes from these experimental models may reflect a combination of the complexity in $\mathrm{HOX}$ regulation with cell-of-origin and cellular context. Whether HOXA9 or other 5' HOXA genes are essential for all MLL-rearranged leukemogenesis or not, they do appear to play a significant role in initiation and maintenance of the disease phenotype.

\section{NPM1}

Nucleophosmin-1 (NPM1) is a ubiquitous nuclear chaperone protein that shuttles between the cytoplasm, nucleoplasm and nucleolus. Translocations within the reading frame at the $\mathrm{C}$-terminus of NPM1 impair the NPM1 protein's nuclear shuttling abilities and result in accumulation of NPM1 in the cytoplasm. Mutations in NPM1 occur in approximately $35 \%$ of adult AML cases (Falini et al., 2009). NPM1-mediated AML also exhibits a HOX signature, though distinct from that of $M L L$-mediated AML. Gene expression analysis revealed elevated $H O X A 9, H O X A 10, H O X B 2, H O X B 6$ and $M E I S 1$ levels in pediatric AML patients. However, a comparison of pediatric NPM1-mediated and MLL-rearranged leukemias showed an upregulation of $H O X B$ genes, in particular $H O X B 2$ and $H O X B 6$, exclusively in NPM1-mutated AML (Mullighan et al., 2007). In a different study, a similar signature was observed in adult AML patients, with elevated levels of HOXA and HOXB genes, as well as co-factors MEIS1 and PBX3 (Verhaak et al., 2005).

\section{FLT3 and MEIS1}

Mutations in the FMS-like tyrosine kinase 3 (FLT3) gene are the most frequent genetic aberration seen in $A M L$, occurring in approximately $25-45 \%$ of patients. The most common mutation, present in $15-35 \%$ of AML cases, is an internal tandem duplication (ITD) caused by a duplication of the juxtamembrane domain, while the second most common mutation is a missense point mutation in exon 20 of the tyrosine kinase domain, which occurs in $5-10 \%$ of AML patients. FLT3 ligand is expressed by most hematopoietic organs, while the FLT3 receptor is predominantly expressed in primitive myeloid and lymphoid progenitors (Stirewalt and Radich, 2003). FLT3 has been proposed to play a role in adult HSC selfrenewal. Expression of FLT3 on human CD34+ cord blood cells is necessary for in vivo myeloid and lymphoid reconstitution (Sitnicka et al., 2003). Interestingly, although flt3 was originally implicated in self-renewal of the mouse HSC pool, upregulation of flt3 in HSCenriched mouse bone marrow fractions was subsequently found to reduce HSC self-renewal capabilities (Adolfsson et al., 2001).

High HOX expression in AML patient samples is correlated with the presence of NPM1 mutations (Verhaak et al., 2005) and also with elevated levels of FLT3 (Roche et al., 2004). Additionally, NPM1-mutated leukemias themselves are strongly associated with higher frequency of FLT3 mutations (Alcalay et al., 2005). In mice studies, Npm1c/Flt3-ITD transgenic mice rapidly developed leukemia in contrast to Npm1c knock-in mice where a significantly longer latency was observed, signalling collaboration between mutant Npm1 and Flt3-ITD proteins in leukemogenesis (Vassiliou et al., 2011; Mupo et al., 2013). Similarly, wild-type Flt3 co-ordinated with NUP98-HOX fusions in co-transduced bone marrow cells to initiate an aggressive AML upon transplantation to mice. In addition, retroviral transduction of pre-leukemic NUP98-HOX myeloid lines with Meis 1 led to leukemic conversion and also a $5-7$ fold increase in Flt3 protein levels (Palmqvist et al., 2012).

Meis 1 is widely implicated in Hox-mediated leukemia. Meis 1 itself has no leukemic activity, however, Meis1 expression was necessary to transform bone marrow cell overexpressing Hoxa9 (Kroon 
et al., 1998). The oncogencity conferred by Meis1 appears to be related to its downstream targets (Argiropoulos and Humphries, 2007). Acomparison of Hoxa9/Meis 1 and Hoxa9 alone immortalised progenitors, demonstrated Hoxa9 and Meis1 co-operate to induce AML and also proliferated in response to Flt3 ligand. This response and Flt3 receptor expression was observed only in Hoxa9/Meis1 transformed cells. Given the exclusivity of this expression, the authors hypothesised Meis1 confers an AML phenotype on nonleukemia Hoxa9 immortalised progenitors through activation of Flt3 (Wang et al., 2005). However, both Flt3 ${ }^{+/+}$and Flt3 ${ }^{-/}$bone marrow progenitors developed rapid AML following Mesi1/Hoxa9 transformation, irrespective of Flt3 genotype (Morgado and Lavau, 2007).

\section{Regulation of hematopoietic HOX genes}

As for other gene families, our understanding of the regulation of HOX genes has been improved recently by advanced technologies such as high throughput sequencing. Along with confirmation of upstream molecules including WNT, RA and CDX (above) cis-features, trans-factors and epigenetic modifiers have been identified that help untangle some of the complexity associated with HOX expression.

\section{Topology}

Integrative epigenomic analysis, including development of assays for transposase-accessible chromatin using sequencing (ATAC-seq, Buenrostro et al., 2013) and chromosome conformation capture-based $(\mathrm{HiC}$ ) approaches (reviewed by Denker and De Laat, 2016), have been used to map gene clusters. Pioneered by the Dubuole laboratory, the differential topology, chromatin state and gene-enhancer contacts of Hox loci have been identified during embryonic development (between E8.5 and E12.5). As predicted, the chromatin structure is highly dynamic during collinear expression of Hox genes. Initiation of transcription resulted in a switch from a single to a bimodal 3D organization whereby newly activated Hox genes progressively clustered into a transcriptionally active compartment (Noordermeer et al., 2011). This spatio-temporal organization coincided with active chromatin marks including $\mathrm{H} 3 \mathrm{~K} 4 \mathrm{me} 3$ that may underpin collinear expression of $\mathrm{Hox}$ clusters. It was later discovered that HoxA and HoxD clusters lie at the junction of two topologically associating domains, which may also help explain the bimodal expression of these clusters during development (Dixon et al., 2012).

\section{Noncoding RNAs}

Long noncoding RNAtranscripts (IncRNAs) affect diverse biological processes through regulation of mRNA stability, RNA splicing, chromatin structure, and sequestration of regulatory molecules including DNA, protein and micro-RNA (miR). Mechanisms of action of IncRNAs which are associated with cell fate decisions in normal and malignant hematopoiesis may be therapeutically targetable (reviewed by Alvarez-Dominguez and Lodish, 2017).

Transcription of IncRNAs within Hox gene clusters (Rinn et al., 2007), along with key non-coding miRs, is now well described with functional significance attributed (reviewed by Kumar and Krumlauf, 2016). Interestingly, these IncRNAs affect gene regulation (positively and negatively) both in cis and in trans on a wide range of $H o x$ and non-Hoxgenes. Alternative start sites, extensive RNA splicing and expression from either coding or non-coding strands results in multiple isoforms of these elements. Comparative analysis between mouse and human loci indicates more noncoding transcripts (including miRs) within or flanking the HoxA cluster relative to other clusters (De Kumar and Krumlauf, 2016). Of particular interest here, a IncRNA embedded between HOXA1 and HOXA2 termed HOTAIRM1, was initially identified as being myeloid-specific and upregulated during granulocyte differentiation (Zhang etal., 2009) when HOXgenes are downregulated. In mouse, Hotairm1 and another isoform Hotairm2 are rapidly upregulated in the presence of RA during myelopoiesis and ESC differentiation (De Kumar et al., 2015).

Additional IncRNAsembedded within the hematopoietically active HOXA locus include HOTTIP which is located 330 bp upstream of HOXA13 and displays bivalent (H3K4me3 and H3K27me3) epigenetic marks (Wang et al., 2011). Hottip may modulate posterior HoxAgene expression by directly binding WDR5-MLL complexes,

Fig. 2. A schematic of HOXA gene expression in normal, engineered and malignant hematopoiesis. 
providing a means for localizing histone methyl transferase activity.

\section{Epigenetic modifiers}

The balance between self-renewal and differentiation of HSCs is regulated by epigenetic mechanisms. HOX genes that evolved from the homeotic selector genes $(H O M-C)$ classically retain a reliance on the balanced regulation by multi-subunit complexes containing MLL (trithorax ortholog) and polycomb gene (PcG) repressor complex (PRC) proteins such as BMI-1 (B cell-specific Moloney murine leukemia virus integration site 1). PcGs were first identified as negative regulators of $\mathrm{HOM}-\mathrm{C}$ genes in Drosophila melanogaster whilst trithorax was identified as a positive regulator maintaining $H O M-C$ expression. As previously mentioned, MLL plays a major role in HOX expression in normal hematopoiesis and dysregulated MLL is associated with aggressive leukemia. Key roles for PRC components in hematopoiesis are also emerging but similar phenotypic outcomes in both gain- and loss-of-function studies demonstrate a significant degree of complexity (Vidal and Starowicz, 2017; Sashida and Iwama, 2017). The two main complexes PRC1 and PRC2 catalyze repressive histone modifications e.g. methylation of histone $\mathrm{H} 3$ at lysine-27 (H3K27me).

$\mathrm{BMI}-1$ forms the core of the PRC1 complex and plays a significant role in $\mathrm{HOX}$ gene regulation. Knockdown of $\mathrm{BMI}-1$ results in upregulation of $\mathrm{HOX}$ genes (Cao et al., 2005) and synergizes with the lysine acetyltransferase KAT6A(MOZ) in maintaining adult HSCs through altered quiescence and senescence (Sheikh et al., 2017). At least six mammalian PRC1 sub-complexes have been identified that have different subunit compositions. BCOR, a component of PRC1.1 was recently identified as a critical regulator of hematopoiesis by inhibiting myeloid cell proliferation and differentiation. Loss of $B C O R$ resulted in upregulation of key hematopoietic $H O X$ genes including HOXA5, HOXA7 and HOXA9possibly by loss of promoter recruitment or regulation of $\mathrm{H} 2 \mathrm{~A}$ ubiquitination (Cao et al., 2016).

Histone modifications are closely linked with DNA methylation state. While MLL is best characterised as a histone methyltransferase, it also contains a DNA methyltransferase homology domain, $\mathrm{CxxC}$, in its $\mathrm{N}$-terminus which binds to unmethylated $\mathrm{CpG}$ residues (Slany, 2009). MII CxxC domain binds to CpG clusters in the Hoxa9 locus, preventing DNA methylation. In the presence of MLL fusion proteins, MLL-AF4 and MLL-AF9, a subset of CpG residues continue to be protected, while the remainder become methylated. Furthermore, MLL fusions increase Hoxa9 expression regardless of whether CpGs became methylated or not (Erfurth et al., 2008), demonstrating other factors besides epigenetic dysregulation are responsible for Hoxa9upregulation in leukemia. MLLalso possesses a SET domain with H3K4 methylation activity in its $\mathrm{C}$ terminus. Loss of the SET domain leads to defects in monomethylation of $\mathrm{H} 3 \mathrm{~K} 4$ and also in DNAmethylation at the same Hox loci (Terranova et al., 2006). Therefore, histone modifications influence DNA accessibility and methylation resulting in regulated gene expression.

Methylation of $\mathrm{CpG}$ islands is linked to dysregulated gene expression in leukemia (Bullinger and Armstrong, 2010). CpG islands in the proximal promoters of $\mathrm{HOX}$ genes are frequently methylated in lymphoid and myeloid leukemia patients. Methylation of $\mathrm{CpG}$ islands is commonly associated with gene silencing implicating $H O X$ downregulation in development of leukemia. However, HOXA9, HOXA10 and HOXB4 are rarely methylated in AML patients, consistent with a role for overexpression of these HOX genes in AML pathogenesis (Saraf et al., 2006; Strathdee et al., 2007). This may be due to aberrant DNA methylation in HOX promoters contributing to different leukemia phenotypes (He et al., 2011). Alternatively, methylation status at $\mathrm{CpG}$ shores within coding regions and/or at remote locus control regions may have a stronger influence over HOX expression than at proximal promoter elements.

\section{Summary and perspectives}

The association of HOX genes with normal and malignant hematopoiesis is long standing and more recently the importance of maintaining HOX expression during the engineering of HSPCs from PSCs has been reported from independent groups. The role of morphogens including RA, WNT, CDX and epigenetic modifiers is well documented. Regeneration and retention of strict spatiotemporal HOX expression may be essential for the in vitro production and maintenance of bona fide HSCs. In addition, targeted repression of specific HOX genes may be critical for curative therapy in malignant hematopoiesis (Fig. 2).

Advanced technologies are increasing our understanding of the spatiotemporal expression of $H O X$ and potential roles of the developmental master regulators they encode. Recent studies using combined single cell tracking and molecular profiling challenges the traditional hierarchical model of hematopoiesis (Velten et al., 2017; Karamitros et al., 2018). This newly proposed continuum in blood cell development creates the potential for further discovery of the criticality of hematopoietic $\mathrm{HOX}$ factors throughout this process. However, lack of HOX-specific tractable models and quality antibodies remain to hamper functional studies. Attaining and retaining appropriate $\mathrm{HOX}$ expression in parallel with functional studies in clinically relevant models will underpin future research into normal, engineered and malignant hematopoiesis.

\section{References}

ACKERMANN M, LIEBHABERS, KLUSMANN J, LACHMANNN (2015). Lost in translation: pluripotent stem cell-derived hematopoiesis. EMBO Mol Med 7: 1388-1402.

ADOLFSSON J, BORGE OJ, BRYDER D, THEILGAARD-MÖNCH K, ÅSTRANDGRUNDSTRÖMI, SITNICKAE, SASAKIY, JACOBSENSEW (2001). Upregulation of Flt3 expression within the bone marrow Lin-Sca1+c-kit+stem cell compartment is accompanied by loss of self-renewal capacity. Immunity 15: 659-669.

ALCALAY M, TIACCI E, BERGOMAS R, BIGERNA B, VENTURINI E, MINARDI SP, MEANI N, DIVERIO D, BERNARD L, TIZZONI L, OTHERS (2005). Acute myeloid leukemia bearing cytoplasmic nucleophosmin shows a distinct gene expression profile characterized by of genes involved in maintenance. Blood 106: 899.

ALHARBI RA, PETTENGELL R, PANDHA HS, MORGAN R (2013). The role of HOX genes in normal hematopoiesis and acute leukemia. Leukemia 27: 1000-1008.

ALVAREZ-DOMINGUEZ JR, LODISH HF (2017). Emerging mechanisms of long noncoding RNA function during normal and malignant hematopoiesis. Blood 130: 1965-1975.

ANDREEFF M, RUVOLO V, GADGIL S, ZENG C, COOMBES K, CHEN W, KORNBLAU S, BARÓN AE, DRABKIN HA (2008). HOX expression patterns identify a common signature for favorable AML. Leukemia 22: 2041-2047.

ARGIROPOULOS B, HUMPHRIES RK (2007). Hox genes in hematopoiesis and leukemogenesis. Oncogene 26: 6766-6776.

ARMSTRONG SA, STAUNTON JE, SILVERMAN LB, PIETERS R, DEN BOER ML, MINDEN MD, SALLAN SE, LANDER ES, GOLUB TR, KORSMEYER SJ (2002). MLL translocations specify a distinct gene expression profile that distinguishes a unique leukemia. Nat Genet 30: 41-47.

AYTON PM, CLEARY ML (2003). Transformation of myeloid progenitors by MLL oncoproteins is dependent on Hoxa7 and Hoxa9. Genes Dev 17: 2298-2307.

AZCOITIA V, ARACIL M, MARTÍNEZ-A C, TORRES M (2005). The homeodomain 
protein Meis 1 is essential for definitive hematopoiesis and vascular patterning in the mouse embryo. Dev Biol 280: 307-320.

BASECKE J, WHELAN JT, GRIESINGER F, BERTRAND FE (2006). The MLL partial tandem duplication in acute myeloid leukaemia. Br J Haematol 135: 438-449.

BIJL J, THOMPSON A, RAMIREZ-SOLIS R, KROSL J, GRIER DG, LAWRENCE HJ, SAUVAGEAU G (2006). Analysis of HSC activity and compensatory. Evaluation 108: 116-122.

BÖIERS C, CARRELHA J, LUTTEROPP M, LUC S, GREEN JCA, AZZONI E, WOLL PS, MEAD AJ, HULTQUIST A, SWIERS G, et al., (2013). Lymphomyeloid Contribution of an Immune-Restricted Progenitor Emerging Prior to Definitive Hematopoietic Stem Cells. Cell Stem Cell 13: 535-548.

BUENROSTRO JD, GIRESI PG, ZABA LC, CHANG HY, GREENLEAF WJ (2013). Transposition of native chromatin for fast and sensitive epigenomic profiling of open chromatin, DNA-binding proteins and nucleosome position. Nat Methods 10: 1213-1218.

BULLINGER L, ARMSTRONG SA(2010). HELP for AML: Methylation Profiling Opens New Avenues. Cancer Cell 17: 1-3.

BUSKE C, FEURING-BUSKE M, ABRAMOVICH C, SPIEKERMANN K, EAVES CJ, COULOMBEL L, SAUVAGEAU G, HOGGE DE, HUMPHRIES RK (2002). Deregulated expression of $\mathrm{HOXB} 4$ enhances the primitive growth activity of human hematopoietic cells. Blood 100: 862-868.

BUSKE C, FEURING-BUSKE M, ANTONCHUK J, ROSTEN P, HOGGE DE, EAVES CJ, HUMPHRIES RK (2001). Overexpression of HOXA10 perturbs human lymphomyelopoiesis in vitro and in vivo. Blood 97: 2286-2292.

CAO Q, GEARHART MD, GERY S, SHOJAEE S, YANG H, SUN H, LIN D, BAI J, MEAD M, ZHAO Z, CHEN Q, CHIEN W, ALKANS, ALPERMANN T, HAFERLACH T, MÜSCHEN M, BARDWELL VJ, KOEFFLER HP(2016). BCOR regulates myeloid cell proliferation and differentiation. Leukemia 30: 1155-1165.

CAO R, TSUKADAY, ZHANG Y (2005). Role of Bmi1 and Ring1Ain H2Aubiquitylation and Hox gene silencing. Mol Cell 20: 845-854.

CHADWICK K, WANG L, LI L, MENENDEZ P, MURDOCH B, ROULEAU A, BHATIA $M$ (2003). Cytokines and BMP-4 promote hematopoietic differentiation of human embryonic stem cells. Blood 102: 906-915.

CHANDA B, DITADI A, ISCOVE NN, KELLER G (2013). Retinoic acid signaling is essential for embryonic hematopoietic stem cell development. Cell 155:215-227.

CHOIKD, VODYANIKMA, TOGARRATIPP, SUKNUNTHAK, KUMARA, SAMARJEET F, PROBASCO MD, TIAN S, STEWART R, THOMSON JA, SLUKVIN II (2012). Identification of the Hemogenic Endothelial Progenitor and Its Direct Precursor in Human Pluripotent Stem Cell Differentiation Cultures. Cell Rep 2: 553-567.

COLLINS C, WANG J, MIAO H, BRONSTEIN J, NAWER H, XU T, FIGUEROA M, MUNTEAN AG, HESS JL (2014). C/EBP $\alpha$ is an essential collaborator in Hoxa9/ Meis1-mediated leukemogenesis. Proc Natl Acad Sci USA 111: 9899-9904.

COLLINS CT, HESS JL (2016). Role of HOXA9 in leukemia: Dysregulation, cofactors and essential targets. Oncogene 35: 1090-1098.

CREAMER JP, DEGE C, REN Q, HOJTK, VALENTINE MC, DRULEYTE, STURGEON CM, LOUIS S, LOUIS S (2017). Human definitive hematopoietic specification from pluripotent stem cells is regulated by mesodermal expression of CDX4. Blood 129: 2988-2993.

CROOKS GM, FULLER J, PETERSEN D, IZADI P, MALIK P, PATTENGALE PK, KOHN DB, GASSON JC (1999). Constitutive HOXA5 expression inhibits erythropoiesis and increases myelopoiesis from human hematopoietic progenitors. Blood 94: 519-528.

DENKER A, DE LAAT W (2016). The second decade of 3C technologies: Detailed insights into nuclear organization. Genes Dev 30: 1357-1382.

DIXON JR, SELVARAJ S, YUE F, KIM A, LI Y, SHEN Y, HU M, LIU JS, REN B (2012). Topological domains in mammalian genomes identified by analysis of chromatin interactions. Nature 485: 376-380.

DOU DR, CALVANESE V, SIERRA MI, NGUYEN AT, MINASIAN A, SAARIKOSKI P, SASIDHARAN R, RAMIREZ CM, ZACK JA, CROOKS GM, GALIC Z, MIKKOLA HKA (2016). Medial HOXAgenes demarcate haematopoietic stem cell fate during human development. Nat Cell Biol 18: 595-606.

DOULATOV S, VO LT, CHOU SS, KIM PG, ARORA N, LI H, HADLAND BK, BERNSTEIN ID, COLLINS JJ, ZON LI, DALEY GQ (2013). Induction of multipotential hematopoietic progenitors from human pluripotent stem cells via respecification of lineage-restricted precursors. Cell Stem Cell 13: 459-470.

ERFURTH FE, POPOVIC R, GREMBECKA J, CIERPICKI T, THEISLER C, XIA Z-B,
STUARTT, DIAZMO, BUSHWELLER JH, ZELEZNIK-LE NJ (2008). MLL protects $\mathrm{CpG}$ clusters from methylation within the Hoxa9 gene, maintaining transcript expression. Proc Natl Acad Sci USA 105: 7517-22.

ERNSTP, FISHER JK, AVERYW, WADES, FOYD, KORSMEYERSJ (2004). Definitive hematopoiesis requires the mixed-lineage leukemia gene. Dev Cell 6: 437-443.

FABER J, KRIVTSOV A V, STUBBS MC, WRIGHT R, DAVIS TN, HEUVEL-EIBRINK M Van Den, ZWAAN CM, KUNG AL, ARMSTRONG SA(2009). HOXA9 is required for survival in human MLL-rearranged acute leukemias. Blood 113: 2375-2385.

FALINI B, BOLLI N, LISO A, MARTELLI MP, MANNUCCI R, PILERI S, NICOLETTI I (2009). Altered nucleophosmin transport in acute myeloid leukaemia with mutated NPM1: Molecular basis and clinical implications. Leukemia 23: 1731-1743.

FERKOWICZMJ, YODER MC (2005). Blood island formation: Longstanding observations and modern interpretations. Exp Hematol 33: 1041-1047.

GOLDIE LC, LUCITTI JL, DICKINSON ME, HIRSCHI KK (2008). Cell signaling directing the formation and function of hemogenic endothelium during murine embryogenesis. Blood 112: 3194-3204.

GOLUB TR, SLONIM DK, TAMAYO P, HUARD C, GAASENBEEK M, MESIROV JP, COLLER H, LOH ML, DOWNING JR, CALIGIURI MA, BLOOMFIELD CD, LANDER ES (1999). Molecular classification of cancer: class discovery and class prediction by gene expression with self-organizing maps: methods and applications to hematopoietic differentiation. Proc Nat Acad Sci USA 96: 2907-2912.

GOUGH SM, SLAPE CI, APLAN PD (2011). NUP98 gene fusions and hematopoietic malignancies: Common themes and new biologic insights. Blood 118:6247-6257.

HE H, HUA X, YAN J (2011). Epigenetic regulations in hematopoietic Hox code. Oncogene 30: 379-388

HORTON SJ, GRIER DG, MCGONIGLE GJ, THOMPSON A, MORROW M, DE SILVA I, MOULDING DA, KIOUSSIS D, LAPPIN TRJ, BRADY HJM, WILLIAMS $\mathrm{O}$ (2005). Continuous MLL-ENL expression is necessary to establish a "Hox code" and maintain immortalization of hematopoietic progenitor cells. Cancer Res 65: 9245-9252.

HUANG Y, SITWALA K, BRONSTEIN J, SANDERS D, DANDEKAR M, COLLINS C ROBERTSON G, MACDONALD J, CEZARDT, BILENKY M, THIESSEN N, ZHAO Y, ZENG T, HIRST M, HERO A, JONES S, HESS JL (2012). Identification and characterization of Hoxa9 binding sites in hematopoietic cells. Blood 119:388-398.

KARAMITROSD, STOILOVAB, ABOUKHALILZ, HAMEY F, REINISCHA, SAMITSCH M, QUEK L, OTTO G, REPAPI E, DOONDEEA J, et al., (2018). Single-cell analysis reveals the continuum of human lympho-myeloid progenitor cells article. Nat Immunol 19: 85-97.

KELLER GM (1995). In vitro differentiation of embryonic stem cells. Curr Opin Cell Biol 7: 862-869.

KENNEDY M, AWONG G, STURGEON CM, DITADI A, LAMOTTE-MOHS R, ZÚÑIGA-PFLÜCKER JC, KELLER G (2012). T Lymphocyte Potential Marks the Emergence of Definitive Hematopoietic Progenitors in Human Pluripotent Stem Cell Differentiation Cultures. Cell Rep 2: 1722-1735.

KRIVTSOV A V., ARMSTRONG SA (2007). MLL translocations, histone modifications and leukaemia stem-cell development. Nat Rev Cancer 7: 823-833.

KROON E (2001). NUP98-HOXA9 expression in hemopoietic stem cells induces chronic and acute myeloid leukemias in mice. EMBO J 20: 350-361.

KROON E, KROSL J, THORSTEINSDOTTIR U, BABAN S, BUCHBERG AM, SAUVAGEAU G (1998). Hoxa9 transforms primary bone marrow cells through specific collaboration with Meis1a but not Pbx1b. EMBO J 17: 3714-3725.

KUMAR AR, HUDSON WA, CHEN W, NISHIUCHI R, YAO Q, KERSEY JH (2004) Hoxa9 influences the phenotype but not the incidence of Mll-AF9 fusion gene leukemia. Blood 103: 1823-1828.

DE KUMAR B, KRUMLAUF R (2016). HOX s and lincRNAs : Two sides of the same coin. Sci Adv 2: 1-8.

DE KUMAR B, PARRISH ME, SLAUGHTER BD, UNRUH JR, GOGOL M, SEIDEL C, PAULSON A, LI H, GAUDENZ K, PEAK A, MCDOWELL W, FLEHARTY B, AHN Y, LIN C, SMITH E, SHILATIFARD A, KRUMLAUF R (2015). Analysis of dynamic changes in retinoid-induced transcription and epigenetic profiles of murine Hox clusters in ES cells. Genome Res 25: 1229-1243.

KYBA M, DALEY GQ (2003). Hematopoiesis from embryonic stem cells: Lessons from and for ontogeny. Exp Hematol 31: 994-1006.

LAWRENCE HJ, CHRISTENSEN J, FONG S, HUY, WEISSMAN I, HUMPHRIES RK, LARGMAN C, LAWRENCE HJ, CHRISTENSEN J, FONG S, HU Y, WEISSMAN I, SAUVAGEAU G, HUMPHRIES RK, LARGMAN C (2014). Loss of expression 
of the Hoxa-9 homeobox gene impairs the proliferation and repopulating ability of hematopoietic stem cells Loss of expression of the Hoxa-9 homeobox gene impairs the proliferation and repopulating ability of hematopoietic stem cells. Blood 106: 3988-3994.

LAWRENCE HJ, HELGASON CD, SAUVAGEAU G, FONG S, IZONDJ, HUMPHRIES RK, LARGMAN C (1997). Mice bearing a targeted interruption of the homeobox gene HOXA9 have defects in myeloid, erythroid, and lymphoid hematopoiesis. Blood 89: 1922-1930.

LAWRENCE HJ, ROZENFELDS, CRUZC, MATSUKUMAK, KWONGA, KÖMÜVESL, BUCHBERGAM, LARGMAN C (1999). Frequent co-expression of the HOXA9 and MEIS1 homeobox genes in human myeloid leukemias. Leukemia 13: 1993-1999.

LEBERT-GHALI C-E, FOURNIER M, KETTYLE L, THOMPSON A, SAUVAGEAU G, BIJL JJ (2016). Hoxa cluster genes determine the proliferative activity of adult mouse hematopoietic stem and progenitor cells. Blood 127: 87-91.

LENGERKE C, DALEY GQ (2012). Caudal genes in blood development and leukemia. Ann N Y Acad Sci 1266: 47-54.

LI D-P, LI Z-Y, SANG W, CHENG H, PAN X-Y, XU K-L (2013). HOXA9 Gene Expression in Acute Myeloid Leukemia. Cell Biochem Biophys 67: 935-938.

LIZ, CHENP, SU R, HU C, LIY, ELKAHLOUNAG, ZUOZ, GURBUXANIS, ARNOVITZ S, WENG H, WANG Y, SHENGLAI L, HUANG H, NEILLY MB, WANG GG, JIANG X, LIU PP, JIN J, CHEN J (2016). PBX3 and MEIS1 Cooperate in hematopoietic cells to drive acute myeloid leukemias characterized by a core transcriptome of the MLL-rearranged disease. Cancer Res 76: 619-629.

MAGNUSSON M, BRUN ACM, LAWRENCE HJ, KARLSSON S (2007). Hoxa9/ hoxb3/hoxb4 compound null mice display severe hematopoietic defects. Exp Hematol 35: 1421-1428.

MCGRATH KE, PALIS J (1997). Expression of homeobox genes, including an insulin promoting factor, in the murine yolk sac at the time of hematopoietic initiation. Mol Reprod Dev 48: 145-153.

MCGRATH KE, PALIS J (2005). Hematopoiesis in the yolk sac: More than meets the eye. Exp Hematol 33: 1021-1028.

MEYER C, HOFMANN J, BURMEISTER T, GRÖGER D, PARK TS, EMERENCIANO M, POMBO DE OLIVEIRA M, RENNEVILLE A, VILLARESE P, MACINTYRE E, et al., (2017). The MLL recombinome of acute leukemias in 2017. Leukemia 27: 2165-2176.

MIKKOLA HKA (2006). The journey of developing hematopoietic stem cells. Development 133: 3733-3744.

MORGADO E, LAVAU C (2007). Brief report Flt3 is dispensable to the Hoxa9 / Meis1 leukemogenic cooperation. Blood 109: 4020-4022.

MULLIGHAN CG, KENNEDY A, ZHOU X, RADTKE I, PHILLIPS LA, SHURTLEFF SA, DOWNING JR (2007). Pediatric acute myeloid leukemia with NPM1 mutations is characterized by a gene expression profile with dysregulated HOX gene expression distinct from MLL-rearranged leukemias. Leukemia 21: 2000-2009.

MUPO A, CELANI L, DOVEY O, COOPER JL, GROVE C, RAD R, SPORTOLETTI P, FALINI B, BRADLEY A, VASSILIOU GS (2013). A powerful molecular synergy between mutant Nucleophosmin and FIt3-ITD drives acute myeloid leukemia in mice. Leukemia 27: 1917-1920.

NAVARRO-MONTERO O, AYLLON V, LAMOLDAM, LÓPEZ-ONIEVAL, MONTES R, BUENO C, NG E, GUERRERO-CARRENO X, ROMERO T, ROMERO-MOYA D, STANLEY E, ELEFANTY A, RAMOS-MEJIA V, MENENDEZ P, REAL PJ (2017). RUNX1c Regulates Hematopoietic Differentiation of Human Pluripotent Stem Cells Possibly in Cooperation with Proinflammatory Signaling. Stem Cells 35:2253-2266.

NG ES, AZZOLA L, BRUVERIS FF, CALVANESE V, PHIPSON B, VLAHOS K, HIRST C, JOKUBAITIS VJ, YU QC, MAKSIMOVIC J, et al., (2016). Differentiation of human embryonic stem cells to HOXA + hemogenic vasculature that resembles the aorta-gonad-mesonephros. Nat Biotechnol 34: 1168-1179.

NOORDERMEER D, LELEU M, SPLINTER E, ROUGEMONT J, DE LAAT W, DUBOULE D (2011). The Dynamic Architecture of Hox Gene Clusters. Science (80-) 334: 122-225.

NORTH TE, DE BRUIJN MFTR, STACY T, TALEBIAN L, LIND E, ROBIN C, BINDER M, DZIERZAK E, SPECK NA, BJORNSON CR., et al., (2002). Runx1 expression marks long-term repopulating hematopoietic stem cells in the midgestation mouse embryo. Immunity 16: 661-672.

PALMQVIST L, ARGIROPOULOS B, PINEAULT N, ABRAMOVICH C, SLY LM, WAN A, HUMPHRIES RK, DC W, KRYSTAL G (2012). The Flt3 receptor tyrosine kinase collaborates with NUP98-HOX fusions in acute myeloid leukemia The Flt3 receptor tyrosine kinase collaborates with NUP98-HOX fusions in acute myeloid leukemia. Neoplasia 108: 1030-1036.

PINEAULTN, ABRAMOVICH C, OHTAH, HUMPHRIES RK, COLUMBIAB, AGENCY C, VZ V, COLUMBIA B, VZ V, COLUMBIA B, et al., (2004). Differential and Common Leukemogenic Potentials of Multiple. Mol Cell Biol 24: 1907-1917.

PINEAULTN, HELGASON CD, LAWRENCE HJ, HUMPHRIES RK (2002). Differential expression of Hox, Meis1, and Pbx1 genes in primitive cells throughout murine hematopoietic ontogeny. Exp Hematol 30: 49-57.

RAMOS-MEJÍA V, NAVARRO-MONTERO O, AYLLÓN V, BUENO C, ROMERO T, REAL PJ, MENENDEZ P (2014). HOXA9 promotes hematopoietic commitment of human embryonic stem cells. Blood 124: 3065-3075.

RAWAT VPS, HUMPHRIES RK, BUSKE C (2012). Beyond Hox: The role of ParaHox genes in normal and malignant hematopoiesis. Blood 120: 519-527.

RINN JL, KERTESZ M, WANG JK, SQUAZZO SL, XU X, BRUGMANN SA, GOODNOUGHLH, HELMS JA, FARNHAM PJ, SEGALE, CHANG HY (2007). Functional Demarcation of Active and Silent Chromatin Domains in Human HOX Loci by Noncoding RNAs. Cell 129: 1311-1323.

ROCHE J, ZENG C, BARÓN A, GADGIL S, GEMMILL RM, TIGAUD I, THOMAS X, DRABKIN HA (2004). Hox expression in AML identifies a distinct subset of patients with intermediate cytogenetics. Leukemia 18: 1059-1063.

SARAF AJ, LAU SF, HE R, ISSA J-PJ, JELINEK J (2006). Distinct DNA methylation patterns of HOX genes in leukemia. Blood 108: 2238.

SASHIDA G, IWAMAA (2017). Multifaceted role of the polycomb-group gene EZH2 in hematological malignancies. Int $J$ Hematol 105: 23-30.

SAUVAGEAU G, LANSDORP PM, EAVES CJ, HOGGE DE, DRAGOWSKA WH, REID DS, LARGMAN C, LAWRENCE HJ, HUMPHRIES RK (1994). Differential expression of homeobox genes in functionally distinct CD34+ subpopulations of human bone marrow cells. Proc Natl Acad Sci USA 91: 12223-12227.

SAUVAGEAU G, THORSTEINSDOTTIR U, EAVES CJ, LAWRENCE HJ, LARGMAN C, LANSDORP PM, HUMPHRIES RK (1995). Overexpression of HOXB4 in hematopoietic cells causes the selective expansion of more primitive populations in vitro and in vivo. Genes Dev 9: 1753-1765.

SAUVAGEAU G, THORSTEINSDOTTIR U, HOUGH MR, HUGO P, LAWRENCE HJ, LARGMANC, HUMPHRIESRK(1997). Overexpression of HOXB3 in hematopoietic cells causes defective lymphoid development and progressive myeloproliferation. Immunity 6: 13-22.

SHEIKH BN, METCALF D, VOSS AK, THOMAS T (2017). MOZ and BMI1 act synergistically to maintain hematopoietic stem cells. Exp Hematol 47: 83-97.e8.

SITNICKA E, BUZA-VIDAS N, LARSSON S, NYGREN JM, LIUBA K, JACOBSEN SEW (2003). Human CD34+ hematopoietic stem cells capable of multilineage engrafting NOD/SCID mice express flt3: distinct flt3 and c-kit expression and response patterns on mouse and candidate human hematopoietic stem cells. Blood 102: 881-886.

SLANY RK (2009). The molecular biology of mixed lineage leukemia. Haematologica 94: 984-993.

STIREWALT DL, RADICH JP (2003). The role of FLT3 in haematopoietic malignancies. Nat Rev Cancer 3: 650-665.

STRATHDEE G, HOLYOAKE TL, SIMA, PARKERA, OSCIERDG, MELO J V., MEYER S, EDEN T, DICKINSON AM, MOUNTFORD JC, JORGENSEN HG, SOUTAR R, BROWN R (2007). Inactivation of HOXA genes by hypermethylation in myeloid and lymphoid malignancy is frequent and associated with poor prognosis. Clin Cancer Res 13: 5048-5055.

STURGEON CM, DITADI A, AWONG G, KENNEDY M, KELLER G (2014). Wnt signaling controls the specification of definitive and primitive hematopoiesis from human pluripotent stem cells. Nat Biotechnol 32: 554-561.

SUGIMURAR, JHADK, HANA, SORIA-VALLESC, DAROCHAEL, LUYF, GOETTEL JA, SERRAO E, ROWE RG, MALLESHAIAH M, WONG I, SOUSA P, ZHU TN DITADI A, KELLER G, ENGELMAN AN, SNAPPER SB, DOULATOV S, DALEY GQ (2017). Haematopoietic stem and progenitor cells from human pluripotent stem cells. Nature 545: 432-438.

SWIERS G, BAUMANN C, O'ROURKE J, GIANNOULATOU E, TAYLOR S, JOSHI A, MOIGNARD V, PINAC, BEE T, KOKKALIARIS KD, YOSHIMOTO M, YODER MC, FRAMPTON J, SCHROEDER T, ENVER T, GÖTTGENS B, DE BRUIJN MFTR (2013). Early dynamic fate changes in haemogenic endothelium characterized at the single-cell level. Nat Commun 4: 2924.

TERRANOVA R, AGHERBI H, BONED A, MERESSE S, DJABALI M (2006). Histone 
and DNA methylation defects at Hox genes in mice expressing a SET domaintruncated form of MII. Proc Natl Acad Sci USA 103: 6629-6634.

THORSTEINSDOTTIR U, MAMO A, KROON E, JEROME L, BIJL J, LAWRENCE HJ, HUMPHRIES K, SAUVAGEAU G (2002). Overexpression of the myeloid leukemia - associated Hoxa9 gene in bone marrow cells induces stem cell expansion. Blood 99: 121-129.

THORSTEINSDOTTIRU, SAUVAGEAU G, HUMPHRIES RK (1997). Hox homeobox genes as regulators of normal and leukemic hematopoiesis. Hematol Oncol Clin North Am 11: 1221-1237.

VASSILIOU GS, COOPER JL, RAD R, LI J, RICE S, UREN A, RAD L, ELLIS P, ANDREWS R, BANERJEE R, GROVE C, WANG W, LIU P, WRIGHT P, ARENDS M, BRADLEY A (2011). Mutant nucleophosmin and cooperating pathways drive leukemia initiation and progression in mice. Nat Genet 43: 470-476.

VELTEN L, HAAS SF, RAFFELS, BLASZKIEWICZS, ISLAM S, HENNIG BP, HIRCHE C, LUTZ C, BUSS EC, NOWAK D, BOCH T, HOFMANN WK, HO AD, HUBER W, TRUMPP A, ESSERS MAG, STEINMETZ LM (2017). Human haematopoietic stem cell lineage commitment is a continuous process. Nat Cell Biol 19: 271-281.

VERHAAK RGW, GOUDSWAARD CS, VAN PUTTEN W, BIJL MA, SANDERS MA, HUGENS W, UITTERLINDENAG, ERPELINCK CAJ, DELWEL R, LÖWENBERG B, VALK PJM (2005). Mutations in nucleophosmin (NPM1) in acute myeloid leukemia (AML): Association with other gene abnormalities and previously established gene expression signatures and their favorable prognostic significance. Blood 106: 3747-3754

VIDAL M, STAROWICZ K (2017). Polycomb complexes PRC1 and their function in hematopoiesis. Exp Hematol 48: 12-31.

WANG GG, PASILLAS MP, KAMPS MP (2005). Meis1 programs transcription of FLT3 and cancer stem cell charcter, using a mechanism that requires interaction with $\mathrm{Pbx}$ and a novel function of the Mesi1 C-terminus. Public Health 106: 254-264.

WANG KC, YANG YW, LIUB, SANYALA, CORCES-ZIMMERMANR, CHENY, LAJOIE BR, PROTACIO A, FLYNN RA, GUPTA RA, WYSOCKA J, LEI M, DEKKER J, HELMS JA, CHANG HY (2011). A long noncoding RNA maintains active chromatin to coordinate homeotic gene expression. Nature 472: 120-126.

WANG Y, NAKAYAMA N (2009). WNT and BMP signaling are both required for hematopoietic cell development from human ES cells. Stem Cell Res 3: 113-125.

WANG Y, YABUUCHI A, MCKINNEY-FREEMAN S, K DUCHARME DM, RAY MK CHAWENGSAKSOPHAK K, ARCHER TK, DALEY J GQ, BY MATTHEW SCOTT EP (2008). Cdx gene deficiency compromises embryonic hematopoiesis in the mouse. Proc. Natl. Acad. Sci. USA 105: 7756-7761.

YEOH E-J, ROSS ME, SHURTLEFF SA, WILLIAMS WK, PATEL D, MAHFOUZ R, BEHM FG, RAIMONDI SC, RELLING M V, PATELA, et al., (2002). Classification, subtype discovery, and prediction of outcome in pediatric acute lymphoblastic leukemia by gene expression profiling. Cancer Cell 1: 133-143.

YODER MC (2014). Inducing definitive hematopoiesis in a dish. Nat Biotechnol 32 : 539-541.

ZHANG X, LIAN Z, PADDEN C, GERSTEIN MB, ROZOWSKY J, SNYDER M, GINGERAS TR, KAPRANOV P, WEISSMAN SM, NEWBURGER PE (2009). A myelopoiesis-associated regulatory intergenic noncoding RNA transcript within the human HOXA cluster. Blood 113: 2526-2534. 


\section{Further Related Reading, published previously in the Int. J. Dev. Biol.}

Early hematopoietic and vascular development in the chick

Hiroki Nagai, Masahiro Shin, Wei Weng, Fumie Nakazawa, Lars Martin Jakt, Cantas Alev and Guojun Sheng

Int. J. Dev. Biol. (2018) 62: 137-144

https://doi.org/10.1387/ijdb.170291gs

Disruption of the aortic wall by coelomic lining-derived mesenchymal cells accompanies the onset of aortic hematopoiesis Alaa A. Arraf, Marella F.T.R. De Bruijn and Thomas M. Schultheiss

Int. J. Dev. Biol. (2017) 61: 329-335

https://doi.org/10.1387/ijdb.170012ts

Hippo signaling components, Mst1 and Mst2, act as a switch between self-renewal and differentiation in Xenopus hematopoietic and endothelial progenitors

Susumu Nejigane, Shuji Takahashi, Yoshikazu Haramoto, Tatsuo Michiue and Makoto Asashima

Int. J. Dev. Biol. (2013) 57: 407-414

https://doi.org/10.1387/ijdb.130010st

Gene regulatory networks governing haematopoietic stem cell development and identity

John E. Pimanda and Berthold Göttgens

Int. J. Dev. Biol. (2010) 54: 1201-1211

https://doi.org/10.1387/ijdb.093038jp

The Notch pathway in the developing hematopoietic system

Anna Bigas, Àlex Robert-Moreno and Lluís Espinosa

Int. J. Dev. Biol. (2010) 54: 1175-1188

https://doi.org/10.1387/ijdb.093049ab

Definitive human and mouse hematopoiesis originates from the embryonic endothelium: a new class of HSCs based on VE-cadherin expression

Estelle Oberlin, Bouchra El Hafny, Laurence Petit-Cocault and Michèle Souyri

Int. J. Dev. Biol. (2010) 54: 1165-1173

https://doi.org/10.1387/ijdb.103121eo

Hematopoietic stem cell emergence in the conceptus and the role of Runx1

Gemma Swiers, Marella de Bruijn and Nancy A. Speck

Int. J. Dev. Biol. (2010) 54: 1151-1163

https://doi.org/10.1387/ijdb.103106gs

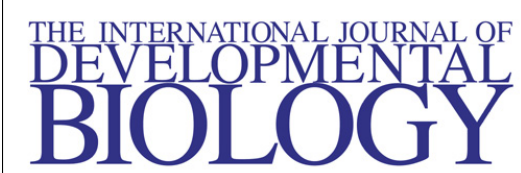

Volume 48 Nos. 5/6

Special issue

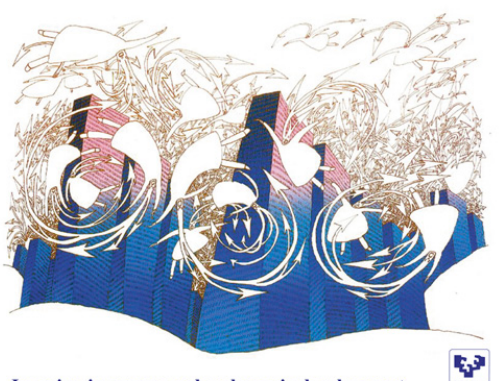

Invasion in cancer and embryonic development is
5 yr ISI Impact Factor $(2016)=2.421$

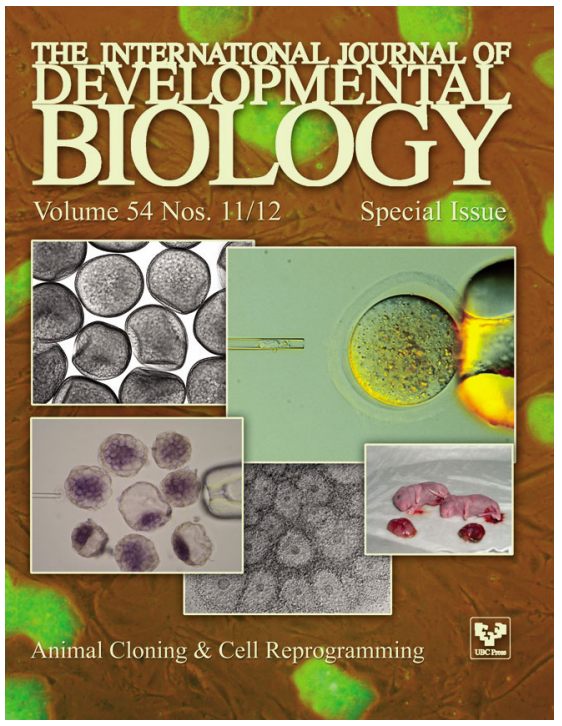

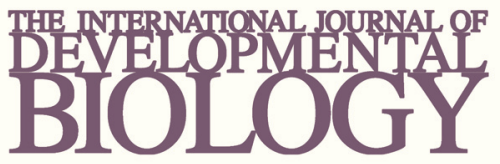

Volume 54 Nos. 6/7
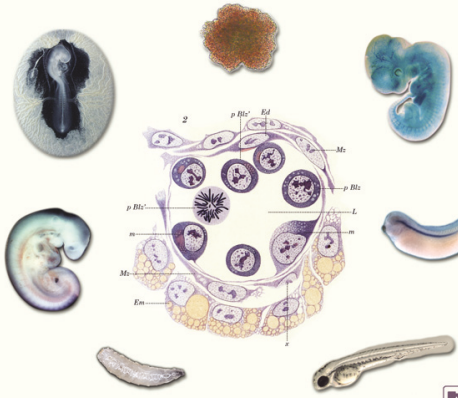

Special Issue

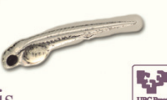

Developmental Hematopoiesis
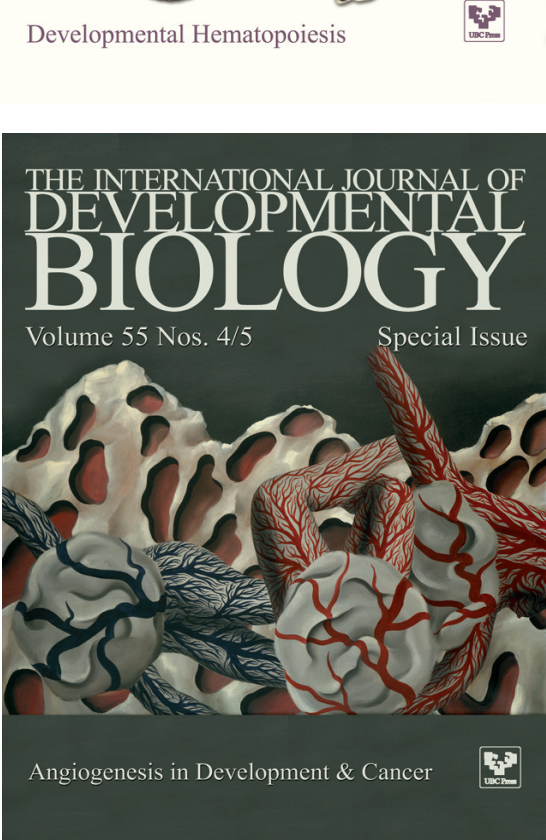